\title{
CYSTICERCOSIS IN SMALL RUMINANTS SLAUGHTERED IN ASWAN SLAUGHTERHOUSE, EGYPT
}

\author{
AHMED K. DYAB ${ }^{1}$; MOHAMMED E. MARGHANY ${ }^{1}$; RAGAA A.OSMAN ${ }^{1}$ \\ and MAHMOUD A.AHMED ${ }^{2}$ \\ ${ }^{1}$ Department of Medical Parasitology, Faculty of Medicine, Assiut University \\ ${ }^{2}$ Department of Parasitology, Faculty of Veterinary Medicine, Aswan University.
}

Received: 20 September 2017; $\quad$ Accepted: 22 October 2017

\begin{abstract}
The aim of the present study was to determine the prevalence, organ distribution, morphological characters and economic importance of Cysticercus ovis and Cysticercus tenuicollis in sheep and goats. A total of 669 sheep and 484goats slaughtered at Aswan Slaughterhouse were carefully examined for these metacestodes. Cysticercus ovis was detected (1.94\%) from slaughtered sheep. Cysticercus tenuicollis was found (13.3\%) in sheep and $(24.2 \%)$ in goats. The prevalence of both C.ovis and C.tenuicollis was higher in females than males and their prevalence was higher in older animals compared to the younger ones. For Cysticercus ovis, the highest infection was found in spring while the highest seasonal infection rate of Cysticercus tenuicollis in slaughtered sheep and goats was noted in autumn season. The infection with C.ovis was only found in the heart, while C.tenuicollis in slaughtered sheep and goats was found mainly in the omentum. These results suggest that the high prevalence of the metacestodes infection in this area is a great concern for both medical and veterinary authorities to design therapeutic and preventive programs to overcome this problem.
\end{abstract}

Key words: Metacestodes, small ruminants, Aswan, Zoonosis.

\section{INTRODUCTION}

Metacestodes are the larval stages of the tapeworms inhabiting in intermediate hosts. The Middle East, southwestern Asia and the Mediterranean coast were considered of high endemic area for metacestodes infection. One of the most common metacestodes which found in infected slaughtered sheep is Cysticercus ovis which may lead to a disease in infected sheep called "sheep measles". Cysticercus ovis is the intermediate larval stage of canid tapeworm, Taenia ovis. The adult tapeworm lives in the intestine of domestic dogs and wild canids (Paula, 2009).

Another important and common metacestodes is Cysticercus tenuicollis which is the larval stage of Taenia hydatigena, a tapeworm of dogs and wild carnivores. The Cysticerci are found in the liver and on the peritoneum in sheep and also in other ruminants including wild ones and pigs. It is called also "long-necked bladder worm". The Cysticerciare most commonly found attached to the omentum, mesentery, live and peritoneum (Kaufmann, 1996).

Corresponding author: Dr. AHMED K. DYAB E-mailaddress: ahmedsaf2001@yahoo.com

Present address: Department of Medical Parasitology, Faculty of Medicine, Assiut University.
The prevalence of infection is considerably high in the world in some countries even more than $85 \%$ of sheep population was found to be infected with this metacestode (Garcia-Marin and Peris-Palau, 1987). The present study was designed to study the prevalence and organ distribution of these metacestodes in slaughtered sheep and goats in Aswan Governorate, southern Egypt. Also the seasonal, age and sex relationship was determined. In addation to the histopathological and Scanning electron microscopy of cysticercus were stdied.

\section{MATERIALS AND METHODS}

Study area: This study was done from August 2015 to July 2016 in Aswan slaughterhouses of Aswan Governorate, southern Egypt.

Animals and post mortem examination: A total of 669 sheep and 484 goats carcasses of both sexes and of different age ranges slaughtered at Aswan slaughterhouse were examined. Visual inspection of the omentum, mesentery, peritoneal cavity, liver, lungs, kidneys, spleen, striated muscles, heart and subcutaneous area of each carcass was done for the presence of C.ovis and C.tenuicollis. Cysts were removed from the condemned organs by careful dissection from surrounding tissues without injuries to the wall of cysts. All the detected larval cestodes 
were collected in separate cellophane bags, then labeled and carried to the laboratory of Parasitology Department, Faculty of Veterinary Medicine, Aswan University in ice box container for further examination. Cysts wash thoroughly with distilled water and then keep in formalin $10 \%$ for histopathological examination, some cysts were used to the macroscopic and unstained process. Some cysts were kept in $5 \%$ cold buffered glutaraldehyde for the examination with scanning electron microscope. This examination was applied for studying the larval cestodes distribution and cyst characterization according to their location in different organs.

\section{Data analysis:}

Data were collected and entered into the computer using SPSS (Statistical Package for Social Science) program for statistical analysis. Data were entered as numerical or categorical, as appropriate. Two types of statistics were done: Descriptive statistics: Qualitative data were expressed as frequency and percent at $95 \%$ confidence interval $(95 \% \mathrm{CI})$.
Analytical statistics: Chi-square test (X2) were used to measure the association between qualitative variables. $\mathrm{P}$ (probability) value considered to be of statistical significance if it is less than 0.05 .

\section{RESULTS}

I. The infection rate and predilection seats of metacestodes in slaughtered animals:

Cysticercus ovis was detected (1.94\%) from slaughtered sheep in Aswan slaughterhouse. The survey of slaughtered goats and sheep revealed a high infection rate with Cysticercus tenuicollis in goats $(24.2 \%)$ and was double than that of sheep $(13.3 \%)$. Females of slaughtered sheep were more susceptible for C.ovis (2.63\%) than males (1.59\%). Moreover, Females of slaughtered sheep and goats were more susceptible for C.tenuicollis $(28.5 \%)$ and $(46.7 \%)$ than males $(5.4 \%)$ and $(20.9 \%)$, respectively. Sheep infected with C.ovis in young and aged animals were $(1.18 \%)$ and $(3.26 \%)$, respectively. Sheep and goat infected with C.tenuicollis in young and aged animals were $(12.03 \%)$ and $(15.5 \%),(24.1 \%)$ and $(25 \%)$, respectively Table $(1)$.

Table 1: The infection rate of metacestodes in slaughtered animals.

\begin{tabular}{|c|c|c|c|c|c|c|c|c|c|c|c|}
\hline Metacestode & Sp. & $\begin{array}{l}\text { Inspected./ } \\
\text { Infected (\%) }\end{array}$ & $\begin{array}{l}\text { Aswan } \\
\text { abattoir }\end{array}$ & M & $\mathrm{F}$ & $\mathrm{X}^{2}$ & P-value & Young & Adult & $X^{2}$ & P-value \\
\hline \multirow[b]{2}{*}{ C.ovis } & \multirow[b]{2}{*}{ Sheep } & Ins. & 669 & 441 & 228 & \multirow[b]{2}{*}{0.205} & \multirow[b]{2}{*}{0.651} & 424 & 245 & \multirow[b]{2}{*}{1} & \multirow[b]{2}{*}{0.312} \\
\hline & & $\begin{array}{l}\text { Inf. } \\
(\%)\end{array}$ & $\begin{array}{c}13 \\
1.94 \%\end{array}$ & $\begin{array}{c}7 \\
1.59 \%\end{array}$ & $\begin{array}{c}6 \\
2.63 \%\end{array}$ & & & $\begin{array}{c}5 \\
1.18 \%\end{array}$ & $\begin{array}{c}8 \\
3.26 \%\end{array}$ & & \\
\hline \multirow{4}{*}{ C.tenuicollis } & \multirow[b]{2}{*}{ Sheep } & Ins. & 669 & 441 & 228 & \multirow[b]{2}{*}{19.2} & \multirow[b]{2}{*}{$<0.0001$} & 424 & 245 & \multirow[b]{2}{*}{0.157} & \multirow[b]{2}{*}{0.692} \\
\hline & & $\begin{array}{l}\text { Inf. } \\
(\%)\end{array}$ & $\begin{array}{c}89 \\
13.3 \%\end{array}$ & $\begin{array}{c}24 \\
5.4 \%\end{array}$ & $\begin{array}{c}65 \\
28.5 \%\end{array}$ & & & $\begin{array}{c}51 \\
12.03 \%\end{array}$ & $\begin{array}{c}38 \\
15.5 \%\end{array}$ & & \\
\hline & & Ins. & 484 & 424 & 60 & \multirow[b]{2}{*}{1.2} & \multirow[b]{2}{*}{0.549} & 448 & 36 & \multirow[b]{2}{*}{0.027} & \multirow[b]{2}{*}{0.869} \\
\hline & Goats & $\begin{array}{l}\text { Inf. } \\
(\%)\end{array}$ & $11724.2 \%$ & $\begin{array}{c}89 \\
20.9 \%\end{array}$ & $\begin{array}{c}28 \\
46.7 \%\end{array}$ & & & $\begin{array}{c}108 \\
24.1 \%\end{array}$ & $\begin{array}{c}9 \\
25 \%\end{array}$ & & \\
\hline
\end{tabular}

For Cysticercus ovis in sheep, the highest infection was found in spring (4.1\%), followed by winter (1.9\%) and summer $(0.5 \%)$. The highest seasonal infection rate of Cysticercus tenuincollis in slaughtered sheep and goats was noted in autumn season $(21.6 \%)$ and $(73.7 \%)$, followed by winter season $(12.4 \%)$ and $(24.0 \%)$, while the lowest infection rate was recorded in spring and summer seasons (11.98\% and $23.7 \%)$ and (11.6\% and $14.3 \%)$, respectively Table (2).

Table 2: The infection rate of metacestodes in slaughtered animals in relation to season

\begin{tabular}{|c|c|c|c|c|c|c|c|c|}
\hline Metacestode & $\begin{array}{l}\text { Animal } \\
\text { Species }\end{array}$ & $\begin{array}{c}\text { Inspected/ } \\
\text { Infected (\%) }\end{array}$ & Spring & Summer & Autumn & Winter & $X^{2}$ & P-value \\
\hline \multirow[b]{2}{*}{ C.ovis } & \multirow[b]{2}{*}{ Sheep } & Inspected & 192 & 180 & 88 & 209 & \multirow[b]{2}{*}{3.06} & \multirow[b]{2}{*}{0.382} \\
\hline & & Infected (\%) & $\begin{array}{c}8 \\
(4.1 \%)\end{array}$ & $\begin{array}{c}1 \\
(0.5 \%)\end{array}$ & 0 & $\begin{array}{c}4 \\
(1.9 \%)\end{array}$ & & \\
\hline \multirow{4}{*}{ C.tenuicollis } & \multirow[b]{2}{*}{ Sheep } & Inspected & 192 & 180 & 88 & 209 & \multirow[b]{2}{*}{6.05} & \multirow[b]{2}{*}{0.109} \\
\hline & & Infected (\%) & $\begin{array}{c}23 \\
11.98 \% \\
\end{array}$ & $\begin{array}{c}21 \\
(11.6 \%) \\
\end{array}$ & $\begin{array}{c}19 \\
(21.6 \%) \\
\end{array}$ & $\begin{array}{c}26 \\
(12.4 \%) \\
\end{array}$ & & \\
\hline & \multirow[b]{2}{*}{ Goats } & Inspected & 135 & 182 & 38 & 129 & \multirow[b]{2}{*}{99.3} & \multirow[b]{2}{*}{$<0.0001$} \\
\hline & & Infected (\%) & $\begin{array}{c}32 \\
(23.7 \%)\end{array}$ & $\begin{array}{c}26 \\
(14.3 \%)\end{array}$ & $\begin{array}{c}28 \\
(73.7 \%)\end{array}$ & $\begin{array}{c}31 \\
(24.0 \%)\end{array}$ & & \\
\hline
\end{tabular}

For C.ovis in sheep, the infection was only found in the heart (100\%). C.tenuicollis in slaughtered sheep and goats was found in the omentum $(62.92 \%)$ and $(67.52 \%)$, followed by mesentry $(12.36 \%)$ and $(21.37 \%)$, liver $(11.24 \%)$ and $(11.11 \%)$, respectively. While urinary bladder $(9 \%)$, diaphragm $(2.25 \%)$ and lung $(2.25 \%)$ were recorded in sheep and not recorded in goats Table (3). 
Table 3: The predilection seats of Cysticercus tenuicollis in different organs.

\begin{tabular}{|c|c|c|c|c|c|c|c|c|c|c|c|c|c|c|c|c|}
\hline \multirow{2}{*}{ 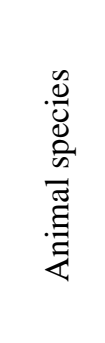 } & \multirow{2}{*}{ 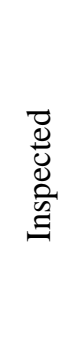 } & \multirow{2}{*}{ 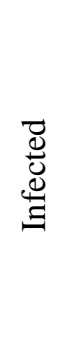 } & \multicolumn{2}{|c|}{ 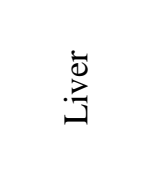 } & \multicolumn{2}{|c|}{$\stackrel{\infty 00}{\Xi}$} & \multicolumn{2}{|c|}{ 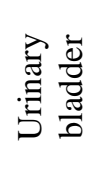 } & \multicolumn{2}{|c|}{ 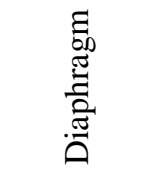 } & \multicolumn{2}{|c|}{$\begin{array}{l}\stackrel{\gtrsim}{E} \\
\stackrel{0}{0} \\
\stackrel{0}{\Sigma}\end{array}$} & \multicolumn{2}{|c|}{ 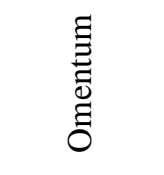 } & \multirow{2}{*}{$\mathrm{X}^{2}$} & \multirow{2}{*}{ P-value } \\
\hline & & & $\begin{array}{l}\vec{d} \\
\stackrel{0}{0} \\
\stackrel{\Perp}{\Xi}\end{array}$ & $d^{2}$ & 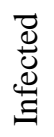 & $b^{2}$ & 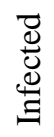 & $b^{\circ}$ & 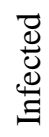 & $a^{2}$ & 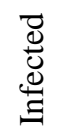 & $a^{2}$ & 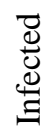 & $d^{0}$ & & \\
\hline Sheep & 669 & 89 & 10 & 11.24 & 2 & 2.25 & 8 & 9 & 2 & 2.25 & 11 & 12.36 & 56 & 62.92 & 195 & $<0.00010 .001$ \\
\hline Goat & 484 & 117 & 13 & 11.11 & 0 & 0 & 0 & 0 & 0 & 0 & 25 & 21.37 & 79 & 67.52 & 253 & $<0.0001$ \\
\hline
\end{tabular}

\section{II.Gross and microscopic examination of metacestodes in slaughtered animals.}

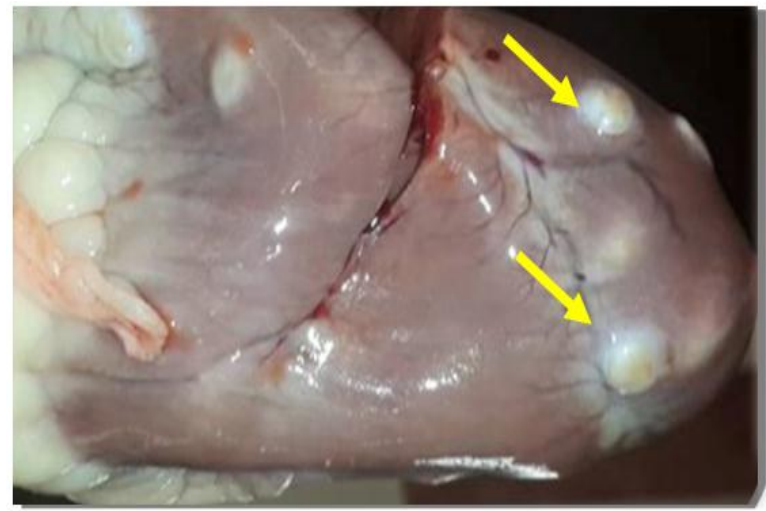

Figure 1: Heart of sheep showing whitish nodules of Cysticercus ovis (arrows) (X5, Bar $=1 \mathrm{~cm}$ ).

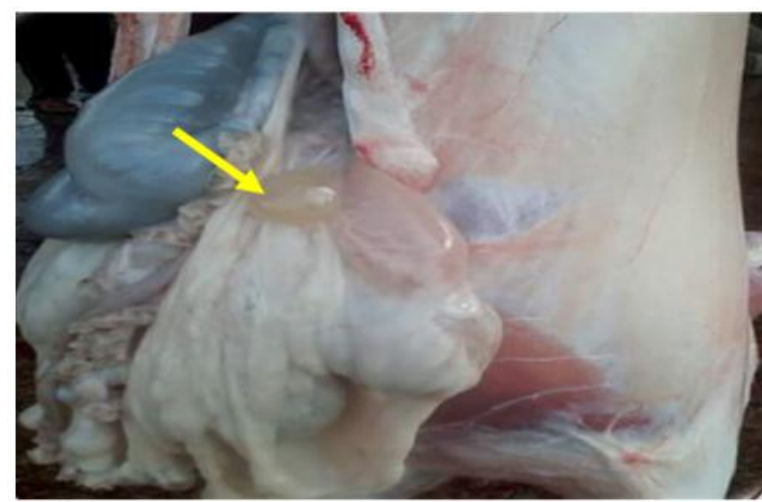

Figure (3): Cysticercus tenuicollis in goat attached to the omentum. (arrow) (X5). It was containing fluid and appears scolex inside it. Omentumgross lesions included accumulation of a large quantity of serofibrinous fluid in the peritoneal and thoracic cavities and a large number of small-sized cysts floating in the fluid of the peritoneal cavity.

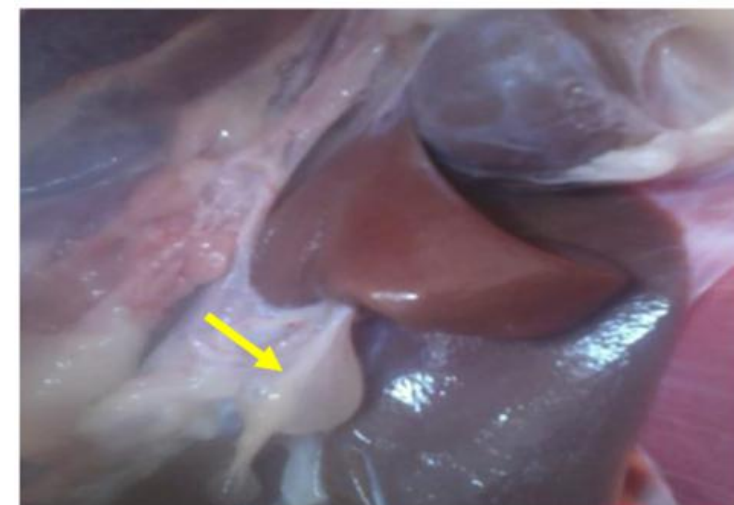

Figure (2): Cysticercus tenuicollis in goat attached to the liver (arrow) (X5). It appears as bladder like gross appearance showing large circular brown to red areas with alternate areas of hemorrhages also appeared on the liver surface and in the parenchyma due to migration of C.tenuicollis.

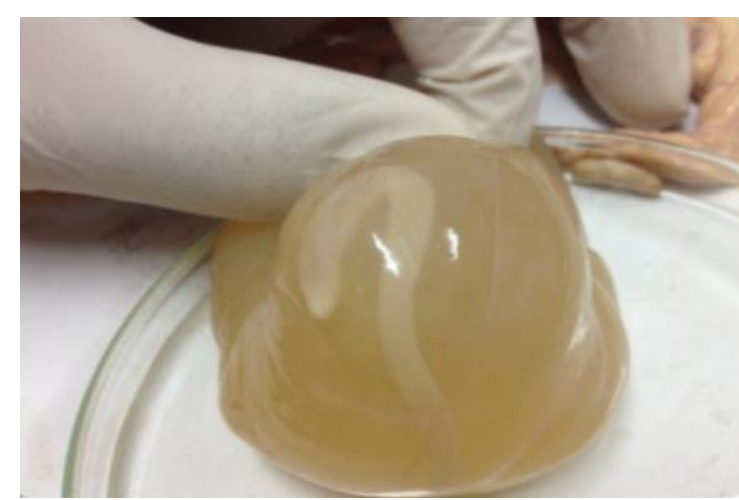

Figure (4): Cysticercus tenuicollis in goat appears as bladder filled with viscous fluid and scolexappeared, followed by immature segments were inside a sticky yellowish sheath (X5, Bar = $4 \mathrm{~cm}$ in diameter). 


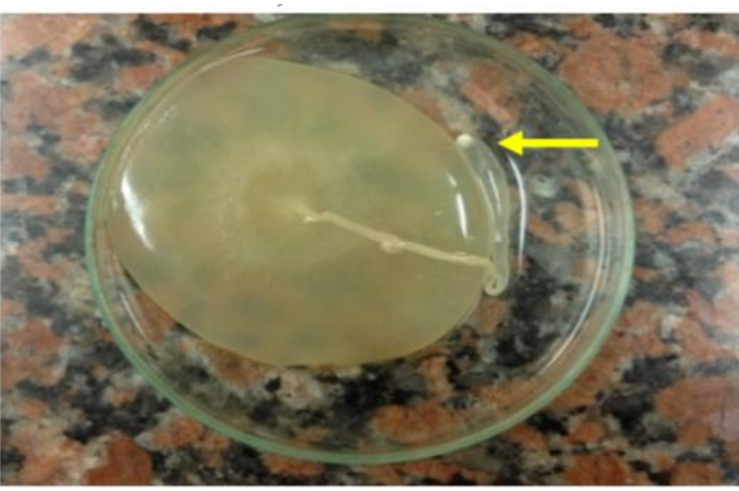

Figure (5): Cysticercus tenuicollis after removing its outer sheath in a petri- dish showing its longitudinal whitish scolex with its suckers (arrow), followed by segmentation attached to bladder like. It was motile in a wave like action (X5).

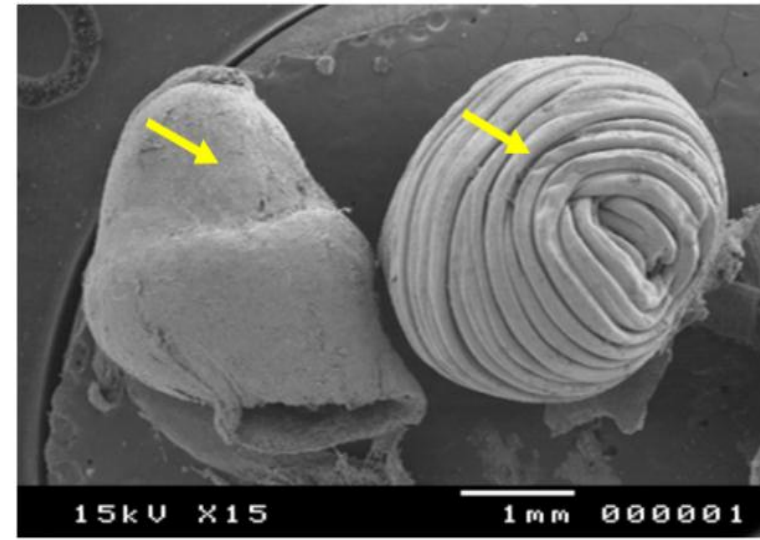

Figure (7): Scanning electron microscopy showing scolex of Cysticercus tenuicollis scolex which appears with circular striations in construction (Right arrow) and a cap tegument covered the scolex (Left arrow). $(15 \mathrm{KVx} 15$, Scale $1 \mu \mathrm{m})$.

\section{DISCUSSION}

I. The infection rate of Cysticercus ovis in slaughtered sheep:

Out of 669 examined sheep in Aswan slaughterhouse, the occurrence of Cysticercus ovis was (1.94\%).This result is in agreement with those reported by Hashemnia et al. (2016) (1.27\%) in Iran. While this result relatively higher than that previously reported by Ali (2013) (0.35\%) in Qena, Egypt, Oryan et al. (2012) $(0.09 \%)$ in Iran. However, this result is lower than those reported by Abdel-Maogood et al. (2005) $(5.66 \%)$ in Cairo, in Egypt, White (1976) in western Australia, Sissay et al. (2008) in Ethiopia, AlQureishy (2008) in Saudi Arabia. In this study, C.ovis was not recorded in goats, while Sissay et al. (2008) in Ethiopia reported C.ovis infection in goats.

II. The infection rate of Cysticercus ovisin slaughtered sheep in relation to sex:

Females of slaughtered sheep (2.63\%) were more susceptible to C.ovis infection than males (1.59\%).

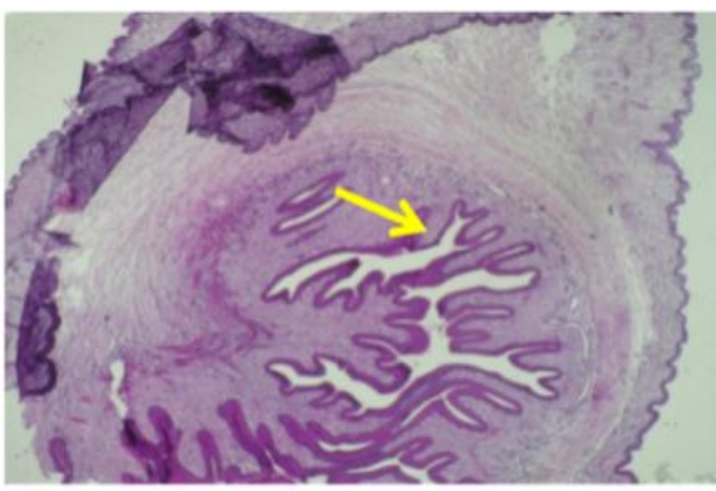

Figure (6): Cross section of Cysticercus tenuicollis stained with H\&E stain (X40). Showing the cystic membrane of C.tenuicollis (arrow) surrounded by a zone of inflammatory cells and fibroblasts.

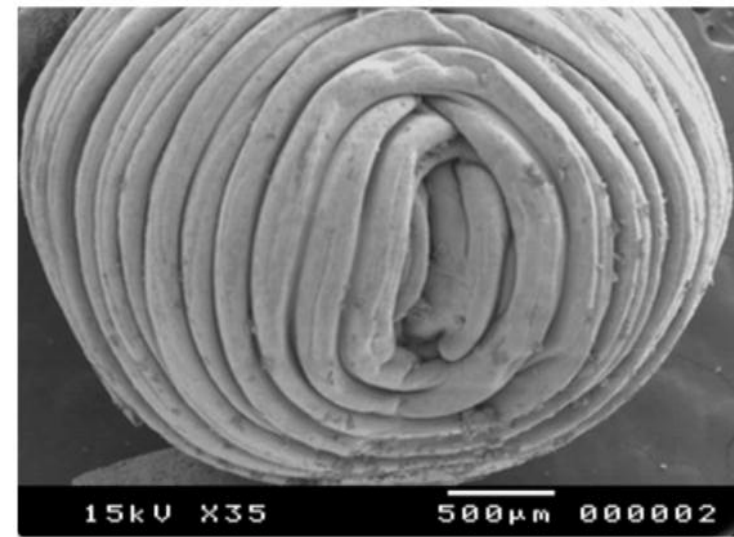

Figure (8): Higher magnification with scanning electron microscope for Cysticercus tenuicollis scolex showing invaginated inverted scolex and its suckers hidden within the scolex. $(15 \mathrm{KVx} 35$, Scale $500 \mu \mathrm{m})$.

There was no statistical difference for ovine cysticercosis in regards to sex $(\mathrm{P}>0.05)$. On the other hand, Hashemnia et al. (2016) reported that the infection rate of C.ovis in slaughtered sheep was significantly higher in males than females $(\mathrm{P}<0.05)$.

III. The infection rate of Cysticercus ovis in slaughtered sheep in relation to age:

Older sheep, over two years old, were more susceptible for Cysticercus ovis (3.26\%) than younger animals, less two years old, $(1.18 \%)$. While there were no statistically significance of C.ovis in slaughtered sheep with regard to age $(\mathrm{P}>0.05)$.

IV. The infection rate of Cysticercus ovis in slaughtered sheep in relation to season:

In regards to seasonal variation of Cysticercus ovis in sheep, the highest infection rate was found in spring $(4.1 \%)$, followed by winter $(1.9 \%)$ and summer $(0.5 \%)$. There was no statistically significance of C.ovis in regards to seasons $(\mathrm{P}>0.05)$. This result was agreed with Hashemnia et al. (2016). While Al- 
Qureishy (2008) found that the highest infection rate $(17.5 \%)$ was in autumn, followed by spring (14.3\%), winter $(9.7 \%)$ and the lowest was in summer $(6.2 \%)$.

V. The infection rate of Cysticercus ovis in slaughtered sheep in relation to predilection seats: The only predilection seats of Cysticercus ovis were in the heart of sheep (100\%). This was agreed with Hashemnia et al. (2016), Gessese et al. (2015) in Ethiopia, Zheng (2016) in China.

\section{The infection rate of Cysticercus tenuicollis in slaughtered sheep and goats:}

In this study, the overall infection rate of C.tenuicollis in 669 sheep and 484 goats slaughtered at Aswan slaughterhouse was $(13.3 \%)$ and (24.2\%), respectively. This result for slaughtered sheep and goats which infected with C.tenuicollis, respectively, was agreed with those reported by Omar et al. (2016) $(16 \%)$ and $(19 \%)$, in upper Egypt Governorates (Qena, Sohag and Aswan), Sultan et al. (2010), Abedl-Maogood et al. (2005), El-Dakhly (2007), Arafa and Fouad (2008) in Egypt, Radfar et al. (2005) in Iran and Scala et al. (2015) in Italy.

While it was higher than that reported by Mirzaei and Rezaei (2015) (4\%) and (4.9\%) in Iran, Bhaskararao et al. (2003), Singh et al. (2015) in India, Jayousi (2014) in Palestine. This result was lower than those reported by Abdulatif et al. (2015) (45\%) and (53.9\%), Sissay et al. (2008), Wondimu et al. (2011) in Ethiopia, Biu and Murtala (2012) in Sudan. While Braae et al. (2015) in Tanzania recoded wise infection rate of C.tenuicollis in sheep and goats $(51.9 \%)$ and $(45.7 \%)$, respectively.

The infection rate of C.tenuicollis was higher in goats as compared to sheep and this may be due to close contact between dogs and goats according to Torgerson et al. (1998). Also, this may due to protective immunity, which early developed in life for most sheep which was under conditions of high infestation of Cysticercus tenuicollis and this immunity regulate the parasite population, whereas goat develops the immunity more slowly. On the contrary, Pathak and Gaur (1982), Akinboade and Ajiboye (1983), Bhaskararao et al. (2003) and Sissay et al. (2008), who found that the rate of infection was higher in sheep than in goats.

\section{The infection rate of Cysticercus tenuicollis in} slaughtered sheep and goats in relation to sex:

The infection rate of C.tenuicollis was higher in female sheep and goats $(28.5 \%)$ and $(46.7 \%)$ than male ones $(5.4 \%)$ and $(20.9 \%)$, respectively. There were very highly significant differences in infection rates with C.tenuicollis among slaughtered sheep $(\mathrm{P}<0.000)$ while among goats were not significant ( $>>0.05)$. This result agreed with Omar et al. (2016), Akinboade and Ajiboye (1983), Abu-Elwafa and AlAraby (2008), Mirzaei and Rezaei (2015). On the other report carried by Senlik (2008) who found that the highest infection rate was observed in male animals (26\%) compared to females (23.9\%). Moreover, Jayousi (2014) found that the sex wise infection rate was lower in females of sheep $(2.7 \%)$ as compared to male ones $(2.15 \%)$.

\section{The infection rate of Cysticercus tenuicollis in} slaughtered sheep and goats in relation to age: The infection rate of C.tenuicollis was higher adult sheep and goats $(15.5 \%)$ and $(25 \%)$ than in the young ones $(12.03 \%)$ and $(24.1 \%)$, respectively. There were no significant differences in infection rates among slaughtered sheep and goats in regard to age $(\mathrm{P}>0.05)$. This result agreed with Akinboade and Ajiboye (1983), Pathak and Gaur (1982), Bhaskararao et al. (2003), Abu-Elwafa and Al-Araby (2008), Senlik (2008), Abdulatif et al. (2015), Mirzaei and Rezaei (2015), Wondimu et al. (2011) and Omar et al. (2016). While Jayousi (2014) reported that the infection rate of C.tenuicollis was higher in young sheep $(4.1 \%)$ than the older ones $(1.9 \%)$. The highest infection rate in older animals than in younger ones might be due to decreased immunity in older animals than younger ones Bhaskararao et al. (2005). Moreover, may be due to close contact between older animals and dogs as mostly of young animals kept indoors than older animals.

\section{The infection rate of Cysticercus tenuicollis in slaughtered sheep and goats in relation to season:}

According to seasonal dynamics of Cysticercus tenuicollis, the infection rate in sheep and goats, respectively, was higher in autumn $(21.6 \%)$ and (73.7\%), followed by winter $(12.4 \%)$ and $(24 \%)$. C.tenuicollis infection with regard to season, there was very highly significant differences in goats $(\mathrm{P}<0.0001)$ while among sheep non-significant $(\mathrm{P}>0.05)$. This result was agreed with Abu Elwafa and Al-Araby (2008).

\section{The infection rate of Cysticercus tenuicollis in slaughtered sheep and goats in relation to predilection seats:}

The infection rate of C.tenuicollis in different organs of sheep and goats showed that the most predilection seats of the cysts were in omentum $(62.92 \%)$ and $(67.52 \%)$, followed by mesentry $(12.36 \%)$ and $(21.37 \%)$, liver $(11.24 \%)$ and $(11.11 \%)$, respectively. While $\mathrm{u}$ rinary bladder (9\%), lung and diaphragm with the same lowest percentage $(2.25 \%)$ for each. The difference between the infection rate of omentum and other organs was very highly significantly associated $(\mathrm{P}<0.0001)$. This is in agreement with Gessese et al. (2015), Abu-Elwafa and Al-Araby (2008), Radfar et al. (2005), Wondimu et al. (2011), Biu and Murtala (2012), Omar et al. (2016), Abdulatif et al. (2015), Fahmi (2014). While Mirzaei and Rezaei (2015) found that the liver wasthe highest 
infection rate for C.tenuicollis in slaughtered sheep and goats (1.64\%) and (2\%), respectively.

Cysticercus ovis appear as small whitish cysts filled with fluid that contain an immature worm this was agree with Omar et al. (2016). The cyst have the size of a grain rice ( 4 to $9 \mathrm{~mm}$ ). Infected meat can have dozens of such cysts. Cysticercustenuicollis in goat was contained fluid and appears scolex inside it. Omentumgross lesions included accumulation of a large quantity of serofibrinous fluid in the peritoneal and thoracic cavities and a large number of smallsized cysts floating in the fluid of the peritoneal cavity. Cysticercustenuicollis stained with $H \& E$ stain showing the cystic membrane of C.tenuicollis surrounded by a zone of inflammatory cells and fibroblasts. This agree with Abdulatif et al. (2015), show that the $C$. tenuicollis hemorrhagic streaks large concentric foci of hemorrhage in the hepatic parenchyma in the migration stage were observed. In histopathological examination, decreased number of hepatocytes, dilution of sinusoids presence of inflammatory cells in portal areas and double layered parasitic cyst formation in chronic stages were evident. Scanning electron microscopy showing scolex of Cysticercus tenuicollis scolex which appears with circular striations in construction and a cap tegument covered the scolex. The bladder wall consists of two main layers. Scanning electron microscopy showed that the outer surface of the bladder is a rough surface consisting of numerous sparsely situated microthriches with no apparent pattern of distribution. They are long and fineas a result of which they are intert wined, forming some thing like a network among which closedareas, lagoons, are formed this agree with Abu-Elwafa and Al-Araby (2008) The thin elongated microthriches are in most cases connected with anther by transverse connections sheep measles (Cysticercus ovis) cause condemnation of carcases or parts of carcases at abattoirs, but they rarely cause ill-effects in the sheep or goats. Small white cysts appear in certain muscles, and while these cannot infect humans, they are considered unacceptable, leading to carcase condemnation. Any affected organs (e.g. hearts) are condemned and cysts are trimmed from muscle in light infections.

\section{REFERENCES}

Abdel-Maogood, S.Z.; Hassan, A.A.; Ramdan, E.I.H. and Mousa, W.M.A. (2005): "Studies on metacestode of sheep with reference to serodiagnosis of Coenuruscerebralis." PhD.Thesis presented to the Faculty of Vet. Medicine, Cairo University.

Abdulatif, A.; Tsegay, A.K. and Mammo, B. (2015): "Prevalence, Cyst Distribution in Visceral Organs and Economic Loss of Cysticercus tenuicollis in Small Ruminants Slaughtered at Bishoftu, Elfora Export Abattoir." American-
Eurasian Scientific Res. J., Vol.10 (4), PP.210220.

Abu-Elwafa, S.A. and Al-Araby, M.A. (2008): "Prevalence of tissue parasites among slaughtered animals in Dakahlia province Mansoura." Vet. Med. J., Vol.10(1), PP.79-91.

Akinboade, O.A. and Ajiboye, A. (1983): "Studies on cysticercosis of small ruminants in Nigeria." Int. J. Zoonoses, Vol. 10(2), PP.164-166.

Ali, A.A. (2013): "Studies on parasitic infestation in some slaughtered animal in upper Egypt." M.V.Sc. Thesis presented to the Faculty of Vet. Medicine, Assiut University, Dep. Food Hygiene.

Al-Qureishy, S.A. (2008): "Prevalence of cestode parasites in sheep slaughtered in Riyadh City, Saudi Arabia." Egypt Soc. Parasitol. J., Vol. 38(1), PP.273-280.

Arafa, M.I. and Fouad, I.A. (2008): "Studies on some internal parasites of goats in Assiut Governorate especially whitch affecting liver." Ass. Univ. Bull. Environ. Res. J., Vol.11(1), PP.57-73.

Bhaskararao, T.; Varaprasad, P.V. and Hafeez, M.D. (2003): "Prevalence of Cysticercus tenuicollis infection in slaughtered sheep and goats at Kakinada, Andhra Pradesh." Parasitic Diseases J., Vol. 27 (2),PP. 126-127.

Biu, A. and Murtala, S. (2012): "Studies on Cysticercus tenuicollis infection in slaughtered sheep and goats in Maiduguri, Nigeria." Continental Vet. Sci. J., Vol.6(1), PP.14-18.

Braae, U.C.; Kabululu, M.; Nфrmark, M.E.; Nejsum, P.; Ngowi, H.A. and Johansen, M.V. (2015): "Taenia hydatigena cysticercosis in slaughtered pigs, goats, and sheep in Tanzania." Trop. Anim. Health Prod. J., Vol. 47(8), PP.1523-1530.

El-Dakhly, K.M.; Hassan, W.H. and Lotfy, H.S. (2007): "Some parasitic and bacterial causes of liver affections in ruminants." BS. Vet. Med. J., $5^{\text {th }}$ Scientific Conference, $\operatorname{Vol}(2)$ PP.62-68.

Fahmi, S.A. (2014): "Studies on Larval Cestodes Infecting Sheep and Cattle." M.V.Sc. Thesis presented to Cairo University, Faculty of Vet. Medicine, Department of Parasitology.

Garcia -Marin, JF. and Peris-Palau, B.(1987): Visceral Cysticercosis in Lambs fattened in Zaragora Province, Spain, Incidence and nature of lesions. Rev, Iberica Parasitol. pp. 195-199.

Gessese, A.T.; Mulate, B.; Nazir, S. and Asmare, A. (2015): "Major metacestodes in small ruminants slaughtered at Dessie municipal abattoir, Eastern Ethiopia: prevalence, cyst viability, organ distribution and economic implications." Comp. Clinic. Patho. J., Vol. 24 (3), PP. 659-668.

Hashemnia, M.; Shahbazi, Y. and Kish, G.F. (2016): "Prevalence and pathological lesions of ovine 
cysticercosis in slaughtered sheep in western Iran." Parasit. Dis.J., PP.1-4.

Jayousi, A.A. (2014): "Prevalence and Molecular Characterization of Cysticercus tenuicollis Cysts in Sheep Slaughtered in Palestine." Thesis presented for M.V.Sc. An-Najah National University, Faculty of Graduate studies in life science (Biology).

Kaufmann, J. (1996): "Parasitic infections of Domestic Animals." A Diagnostic Manual." Birkha, user Verlag, Basal, Schweiz.

Mirzaei, M. and Rezaei, H. (2015): "Role of goats and sheep in the epidemiology of Cysticercus tenuicollis in Tabriz, Northwest Iran." Comparative Clinical Pathology. J., Vol. 24(2), PP.441-444.

Omar, M.A.E.; Elmajdoub, L.O.; Al-Aboody, M.S.; Elsify, A.M.; Elkhtam, A.O. and Hussien, A.A. (2016): "Molecular characterization of Cysticercus tenuicollis of slaughtered livestock in Upper Egypt Governorates." Asian Pacific Trop. Biomed. J., Vol.6(8), PP.706-708.

Oryan, A.; Goorgipour, S.; Moazeni, M. and Shirian, S. (2012): "Abattoir prevalence, organ distribution, public health and economic importance of major metacestodes in sheep, goats and cattle in Fars, southern Iran." Trop. Biomed. J., Vol. 29(3), PP.349-359.

Paula (2009): "Handbook for the Control of Internal Parasites of Sheep." Page 8.

Pathak, K.M.L. and Gaur, S.N.S. (1982): "The incidence of adult and larval stage Taeniahydatigena in Uttar Pradesh (India)." Vet. Parasitol. J., Vol.10(1), PP.91-95.

Radfar, M.H.; Tajalli, S. and Jalalzadeh, M. (2005): "Prevalence and morphological characterization of Cysticercus tenuicollis (Taeniahydatigena cysticerci) from sheep and goats inIran." Vet. Arhiv. J., Vol. 75(6), PP.469-476.

Scala, A.; Pipia, A.P.; Dore, F.; Sanna, G.; Tamponi, $\quad$ C.; Marrosu, R.; Bandino, E.; Carmona, C.; Boufana, B. and Varcasia,
A. (2015): "Epidemiological updates and economic losses due to Taeniahydatigena in sheep from Sardinia, Italy." Parasitology Res. J., Vol. 114(8), PP.3137-3143.

Senlik, B. (2008): "Influence of Host Breed, Sex, and Age on the prevalence an intensity of Cysticercus tenuicollis in sheep." Turkey J. of Animal and Vet. Advanceca,Vol.7(5), PP.548551.

Singh, B.B.; Sharma, R.; Gill, J.P. and Sharma, J.K. (2015): "Prevalence and morphological characterisation of Cysticercus tenuicollis (Taeniahydatigena cysts) in sheep and goat from north India. "Parasit. Dis.J., Vol.39(1), PP.80-84.

Sissay, M.M.; Uggla, A. and Waller, P.J. (2008): "Prevalence and seasonal incidence of larval and adult cestode infections of sheep and goats in eastern Ethiopia." Trop. Anim. Health Prod. J.,Vol. 40(6), PP. 387-394.

Sultan, K.; Desoukey, A.Y.; Elsiefy, M.A.; Elbahy, N.M. (2010): "An abattoir study on the prevalence of some gastrointestinal helminths of sheep in Gharbia Governorate, Egypt." Global Veterinaria. J., Vol.5(2), PP.84-87.

Torgerson, P.; Williams, D. and Abo-Shehada, M. (1998): "Modelling the Prevalence of Echinococcus and Taenia Species in Small Ruminants of Different Ages in Northern Jordan." Vet. Parasitol. J.,Vol.79(1),PP.35-51.

White, J.B. (1976): "Incidence of Cysticercus ovis in sheep and lambs at Albany, Western Australia." Aust. Vet. J., Vol. 52 (3), PP.118122.

Wondimu, A.; Abera, D. and Hailu, Y. (2011): "A study on the prevalence, distribution and economic importance of Cysticercus tenuicollis in visceral organs of small ruminants slaughtered at an abattoir in Ethiopia." Vet. Med. and Animal Health J., Vol. 3(5), PP. 67-74.

Zheng, Y. (2016): "Taenia ovis: an emerging threat to the Chinese sheep industry?" Parasites and Vectors. J., Vol. 9(1), PP.415. 


\section{داء الكيسات المذنبة في المجترات الصغيرة المذبوحة في مجزر أسوان بمحافظة أسوان \\ احد دياب ، محمد مبرغنى ، رجاء عثمان ، محمود عبل الحمبإ /حمد}

Email: ahmedsaf2001@yahoo.com Assiut University web-site: www.aun.edu.eg

تم دراسة وجود عدوى أطوار يرقات الديدان الثريطية بين الحيو انات المذبوحة من الأغنام و الماعز وقد أجريت الدراسة في مجزر

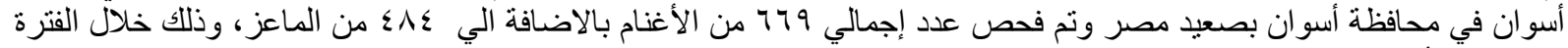

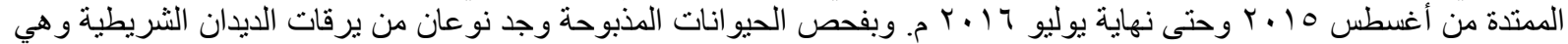

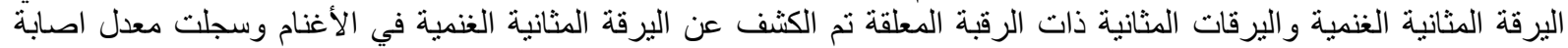

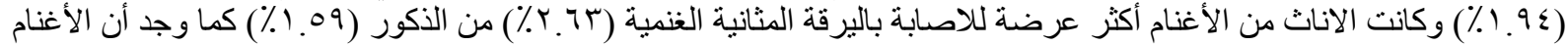

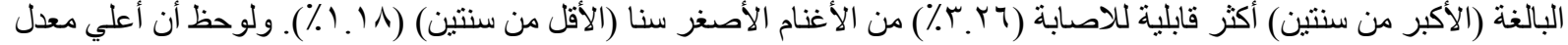

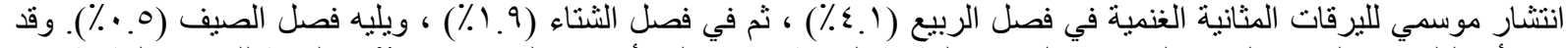

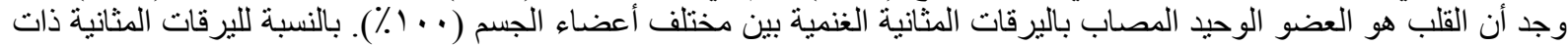

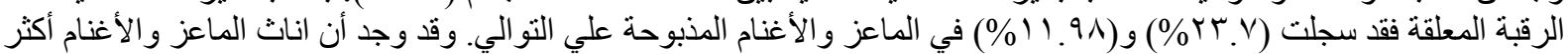

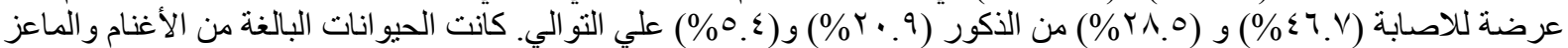

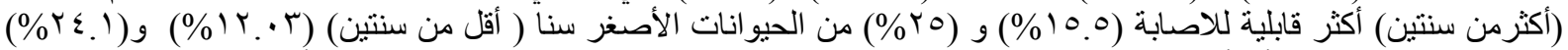

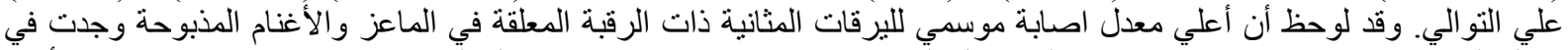

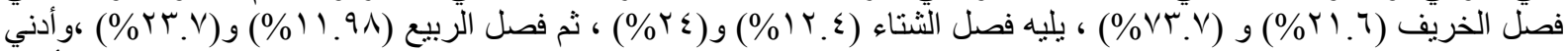

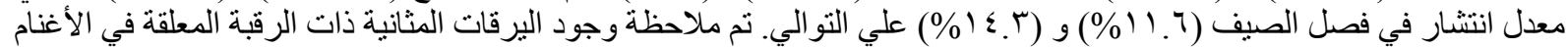

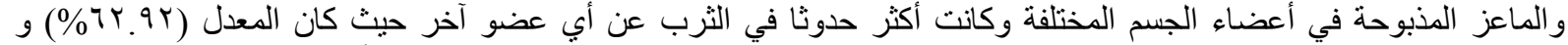

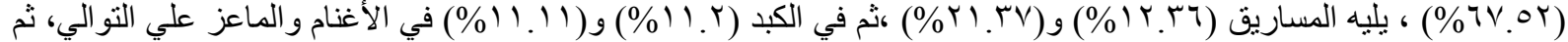

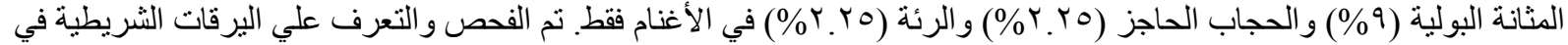

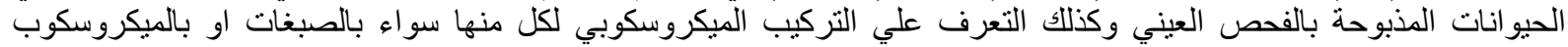

